\title{
鐵鎙 第二十年，第九號
}

昭和九年九月云十五撥行

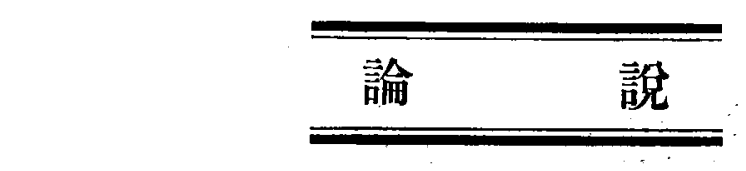

鋼の燒入膨脹速度に及法諸元素の影響

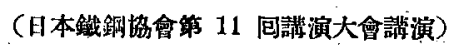

$\begin{aligned} \text { 村 上 武 次 郎 } & \\ \text { 八 } & \text { 田 篤 敬 }\end{aligned}$

THE EFFECTS OF SPECIAL ELEMENTS ON THE VELOCITY OF EXPANSION DUE TO MARTENSITIZATION DURING QUENCHING OF STEEL.

by Takejirô Murakami and Atuyoshi Hatta.

SYNOPSIS:-A self-recording apparatus of expansion-time curve during quenching of steel was constructed. With this apparatus, the expansion-time curve was obtained for 4 carbon steels and 32 steels containing less than $2 \%$ of $\mathrm{Mn}, \mathrm{Ni}, \mathrm{Co}, \mathrm{V}, \mathrm{Cr}, \mathrm{Si}, \mathrm{W}$ or $\mathrm{Mo}$, with nearly eutectoid carbon content. The quenching temperature varied from $850^{\circ} \mathrm{C}$ to $1,10 \mathrm{CC}^{\circ}$, the quenching melium being oil.

The velocity of expansion due to martensitization was calculated by the follorsing formula. $d x / d t=K(a-x)$, in which $x$ shows the amount of martensite formed at time, $t, a$ amount of martensite after cooled to room temperature, and $K$ a constant. Then, the velocity of martensitization is shown by $d \dot{x} / d t=1 / 2 \cdot K a$, when $x$ is $1 / 2 \cdot \dot{a}$

By the value $1 / \cdot \cdot K_{a}$ the effects of special elements and quenching temperature on the velocity of expansion were studied. The values $1 / 2 \cdot \mathrm{Ka}$ and a change with the rise of quenching temperature, the maximum value being the case quenched from $900 \sim 1,000^{\circ} \mathrm{C}$ The be rining temperature of martensitization generally falls, as the quenching temperature rises.

In the plain carbon steel of nearly eutectoid composition the martensite is formed by oil-quenehing, while in those of the hyper-and hypo-eutectoid composition the troostite is formed by the same operation. In alloy steels te sted in the present work, the martensitization takes place on quencbing in oil, except in $1.94 \%$ cobalt steel. The velocity and amount of expansion of vanadium steels are small and those of tungsten steels. are large. Among the steels containing: 0.5 and-1\% of special element added, manganese steel has the largest, velocity of expanaion, while among those with $15 \%$ or $2 \%$ of special element, tungsten steel is the largest.

I. 精言 鋼の燒入に際しオースデイトよりマルテン サイトイ變化する時著しを膨脹を件る。。從つて鋼の各部分 一样に冷却せないときは相當の歪力と歪を附隨する。而し て發生する歪力が粘性變形の範圍を超過するときは憢割を 生する。故に燒入膨脹速度郎ちオーステナイトのマルテン サイト化速度並に膨脹量の大小忹焼割の難易に關係するて 之大でする。而して其膨脹速度並儿膨脹量を支配する因子 は種をあるか銅の組成、燒入溫度、冷却速度等はそれ至 大の影響を及㾏す。因つて著者等山此等の影響を知るため 鋼の燒入几際して起る長さの變化を自記する裝置を潅作 し、之に因つてォーステナイトのマルテッサイトルる膨 脹速度並に膨膨量を測定した。鋼乃組成は大體に於て炭素

Y:*) 東北蒂闌大學金属材料研究所

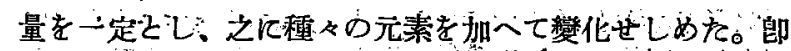

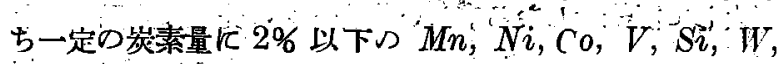
$C r$ 及び $M o$ を夫そ種々なる割合に配合して造つを陚料を 用ひた。又燒入溫度を種々飞變化し：冷却速度は一定飞す るため油燒入の場合のみを測定した。

II. 測定裝置 鋼の燒入に於てはその冷却速度が非常 に速なるれめ、普通使用せる熱膨脹計に㑐りその彎化を测 定するとと度出秉ない。銅の燒入の際に起る長さの變化を 研究する目的を以つて從來㮔々の裝置が考案された，その 中 2 3 を舉げると. 本多式燒入研究裝置 1)、は試料棒と 標潐榀との示差膨镺の變化を反射鏡儿傅人、之强い光を

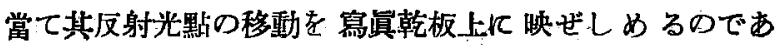

1) 本多、钱质銅の研究 2(大正9)、33e 


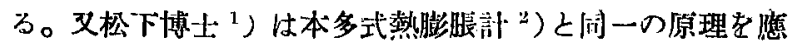

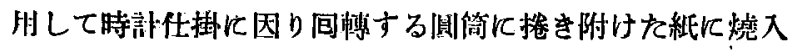
膨脹の變化を自記せしめる裴置を将策して鈿の燒入に就い て研究された。Bain 及び Waring：)は試料の一端に接觸 せしめたダイヤルゲーヂの指針の動きとストッブウオッテの 示す秒㻌とを活趿寫真に撮影して、燒入の際に起る長さの

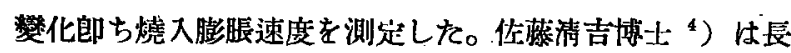
さ一溫度曲線メは閔さー時間曲線を自記せしさる精坞なる 装置を考案し、之に因て炭素鋼つ燒入に就て研究された。

本研究に於ては稍太き試片を使用して、煖入の間に起る 長さ一眭間曲線を自記せしむるために松下博士考案の裝置 を改造して用ひた。第 1 圖は其装置を示す。圖に於で $\mathbf{S}$

第 1 圆 焅入膨脹一時閒自記㱔置

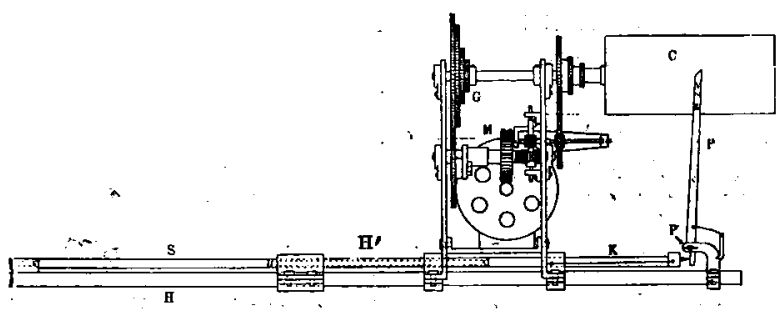

は試片で直徑 $8 m m$ 、長さ $200 \mathrm{~mm}$ である。かく此較的大な る試片を使用したのは酸化脫崖に因る影響を成る可く少く するためと，又成るへく實際作業に近いやらにらの目的で ある。：H は耐熱合金の支持棒で實驗の月的に因りては石 英管を使用した。然る時は而熱合金に因る膨脹收縮の影響 を除く事が出來る。’又 $\mathrm{H}^{\prime}$ は石英管で K は不變鋼である。 試片の燒入に際して起る長さの變化は～ $\mathrm{P}$ なる不變鋼製の 儗の先に取付けたペンに運動を與人、一定速度で国轉する 圆筒 Cに捲き付けた曲線力眼紙上に長さの變化を３5 倍に 搌大して記錄せしむる。との場合ペンの先端は支點 $\mathrm{P}^{\prime}$ を 中心に圆筒紙上に或る曲線を描いて運動するに由て圆筒紙 の縱軸は $\mathrm{P}^{\prime}$ を心とし、 $\mathrm{P}^{\prime}$ とペン先との距離を恔徑とす る圆弧上り成る曲線方眼紙を用みた。 又 $\mathrm{M}$ は $1 / 16$ 馬力 の電動機であり、G ば荀車の組合せ部分で、その組合せに 依り圆筒 C の回轉數を任意變化するてとが出來る。

又燒入液は常に鯨油を朋ひ、一粎に冷却せしむるため。 靽に由て油中に空氣を邆つて㩭姓した。

1) 松下、钱立制、8(大正 11)、557。

2) 本多、東北帝大理科報告 6(1917)、203。众屬の研究 1(1924)、 537。

(3) Bain and Waring. Trans, Amer. Soc. Steel Treat. 15 (1929), 69。

4) 恢蕌、金閩の研究 9(1932)、174 同上 10(1933)，68。

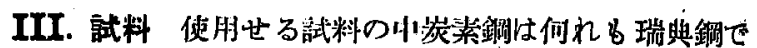

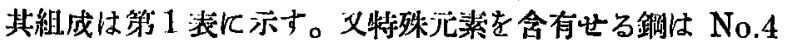

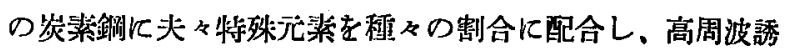

第 1 表炭素鋁の化學成分

$\begin{array}{llllll}\text { 岸染鎆 } & C \% & M n \% & S i \% & P \% & S \% \\ \text { No. 1 } & 0.73 & 0.18 & 0.23 & 0.082 & 0.015 \\ \text { No. 2 } & 0.92 & 0.24 & 0.24 & 0.028 & 0.025 \\ \text { No. 3 } & 1.06 & 0.57 & 0.04 & 0.015 & 0.028 \\ \text { No. 4 } & 1.12 & 0.17 & 0.25 & 0.034 & 0.020\end{array}$

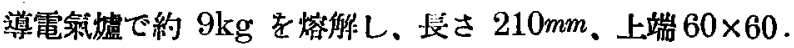

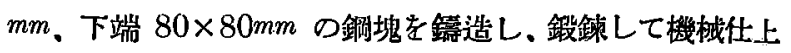
をなし、所要の大さにした。第 2 表は其分析結果を示す。

第 2 表各種鋼の化學成分

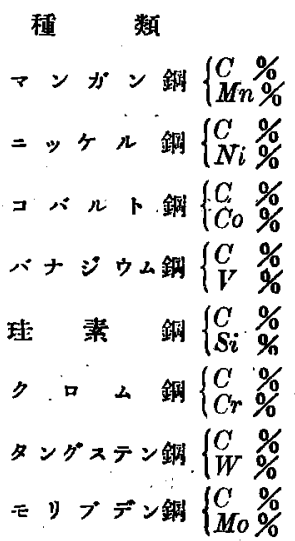

\begin{tabular}{cccc}
\multicolumn{4}{c}{ 試料番㩆 } \\
No.1 & No.2 & No.3 & No.4 \\
0.81 & 0.96 & 0.85 & 0.94 \\
0.66 & 1.14 & 1.55 & 2.01 \\
1.10 & 0.97 & 1.20 & 0.80 \\
0.50 & 0.90 & 1.49 & 1.91 \\
0.65 & 0.75 & 0.65 & 0.89 \\
0.55 & 1.00 & 1.53 & 1.94 \\
0.80 & 0.99 & 0.71 & 0.92 \\
0.30 & 0.65 & 0.93 & $1 \cdot 27$ \\
0.83 & 0.87 & 0.81 & 0.85 \\
0.71 & 0.86 & 1.34 & 2.05 \\
0.83 & .0 .65 & 0.79 & 072 \\
0.53 & 0.99 & 1.49 & 2.07 \\
0.92 & 0.81 & 0.82 & 0.93 \\
0.92 & 1.44 & 1.76 & 2.22 \\
0.84 & 0.84 & 0.95 & 0.88 \\
0.97 & 1.52 & 1.99 & 2.62
\end{tabular}

IV. 炭素鋼の燒入曲楾 第 2〜5. 圖は 4 糧の炭素鋼に 就て得たる燒入膨脹一時間曲線を示す。此等の曲線は曲線 方腿紙に自記せしめたものを普通方眼紙に書を改めたもの でする゙。縱軸は膨脹を表はし横軸は時閒を表はす。又オ一 ステナイトの膨脹係數は溫度に由て大差なく殆ど一定なる 故、像め冷却に因るオーステナイトの收縮と溫度の關係を 測定して置く時は、縱軸に由て溫度を示寸ととが出來る。 此際ペンの運動は試片の長さの變化を 35 倍に搌大して示 すが故に、オーステナイトの線膨脹係數 $\propto$ を 0.000015 とすれば、ペンの運動 $10 \mathrm{~mm}$ は約 $100^{\circ}$ に相㗬する。圖 の點線上に記せる溫度はかくして定めたすの之に由つて變 化の起る溫度を知ることが出來る。

第 2 圆は $0.73 \% \mathrm{C}$ の炭素鋼の燒入曲線で、 $\mathrm{AB}$ はオ ーステナイトの收縮を表はし、 $\mathrm{BC}$ は $\mathrm{Ar}^{\prime}$ 變態郎オース テナイトよりトルースタイトへの變化による膨脹を示す。 叉 CD は變態後の收縮を示するのである。此鋼は本實驗 の如き油燒入に由ては燒入の間にトルースタイトに變化 し、マルテンサイトを生ぜをんのでする。而して $\mathrm{Ar}^{\prime}$ 變 態は焼入溫度が上寔するに從ひ、其開始點郎 B 點は次第 

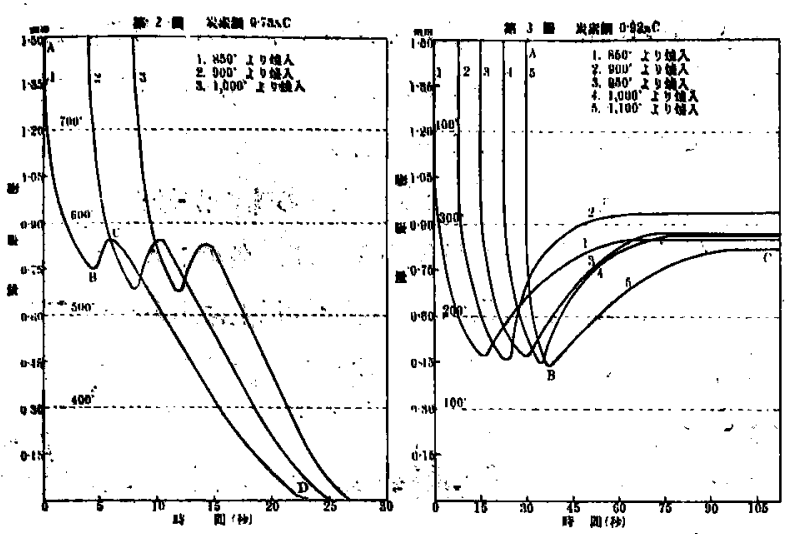

に降下し、其膨脹量ば次第に增加する傾向がある。

第 3 及 4 圖は䈐素量 $0.92 \%$ 及び $1.06 \%$ の試料の燒入 曲線で、此場合には 600〜 500 ス於ける膨脹は認められ シレが、200 オーステナイトの收蹜を表はし、 $\mathrm{BC} は \mathrm{Ar}^{\prime \prime}$ 變態郎ちオ ーステナイトよりマルテンサイトへの變化に歸因する膨脹 を示ナるものである。而して B 點は試料のマルテンサイ

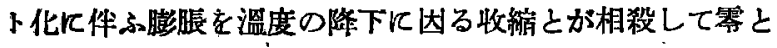
なる點である。故に正確にはマルテンサイト化の開始溫度 ではなく、置の開始點は B 點よりる少しく高以筈である が、此 B 點を以てマルテンサイト化の開始溫度として大 なる差はない。之に因て見る時はマルテンサイト化の開始

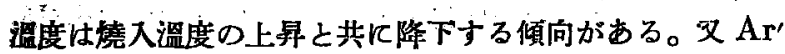

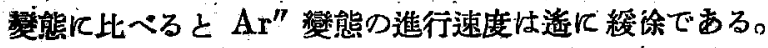
一般にマルテンサイト化速度は最初は急速て後徐に進行す る。併し其速度及膨脹量は燒入溫度几因て異をり、此場合 に於ては $900^{\circ} \mathrm{C}$ 燒入の場合が其速度及樾脹量共に最大で すり。堯入溫度更に上昇する時は變化の速度㜊くなり膨脹 量も減少する。是れはオーステナイトが完全にマルランサ イト化せないをめで、燒入溫度の高いるのは殘留オーステ ナイトを有するととは既によく知られた所でする。

又第 5 圖仕炭素量 $112 \%$ の試料D燒入曲線で。此場 合於ては 0.73\% Cの試料之同㥞にオーステナイトは 600 500 K於てトルースタイトル變化し、 、ルテンサ イトを生ぜな。之に由て見れば孷素銅俚共析組織附近の むのがマルテンサイト化し易く：それ上り岑素量の多いる のむ少レものも゙ルースタイトが表はれ易りてとが知られ

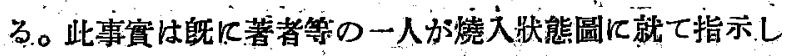
キ所である。 $\left.{ }^{1}\right)$

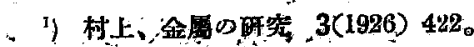

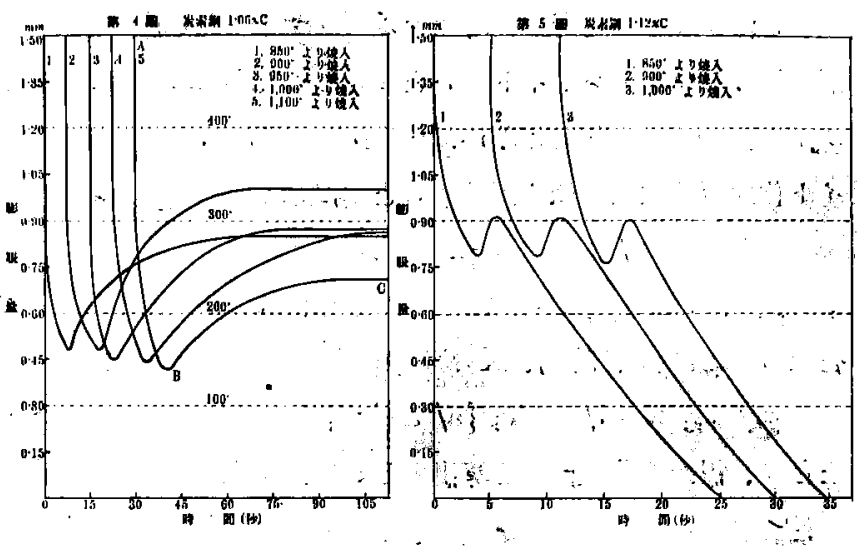

V. オーステナイトのマルテンサイト化速度の計算 鋼 の燒割れは主として其のマルテンサイト化による膨脹速 度、膨脹量並にマルテンサイト化開始溫度關係するすの である。所で膨脹量並に、ルテンサイト化開始溫度は燒入 曲線に由て知るでとが出來るが、膨脹速度は次の如くにし て計算し比较す名てとにした。

前に述べを如くマルテンサイト化の變化は其初めは一般 に速度大きく變化 進むに從つて次第にその速度綏慢とな る。是れマルテンサイト化の始めには變化すべきオーステ ナイトの量が多いけれを゙變化の進行に從ひ變化すべす ーステナイトの量が炇第に減少するをあである。因て第6

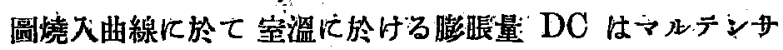

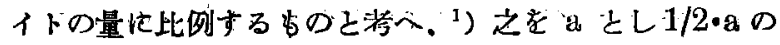

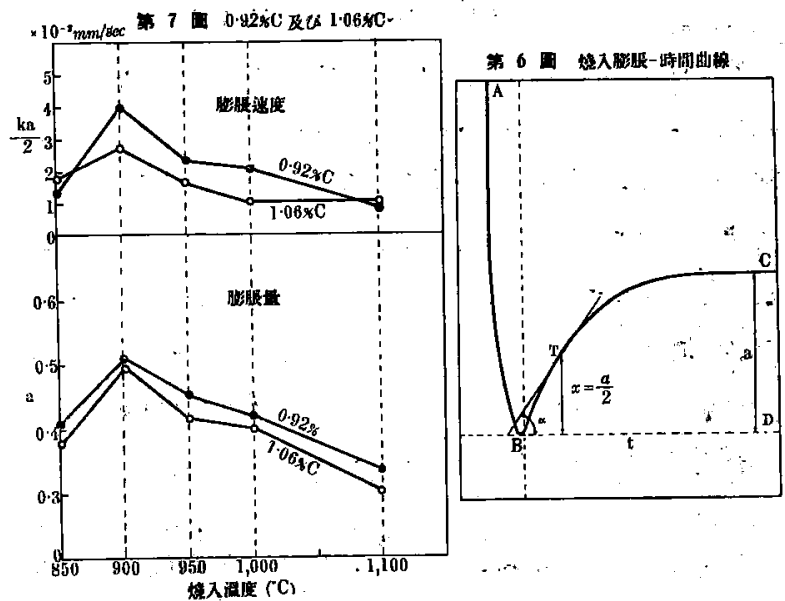

マルテンサイトが生じを特つ速度を以てマルテンザイト化 速度を表はし之を以て比較することっしき。

上述の栐に膨脹速度が次第に緩慢之なるのはオーステナ

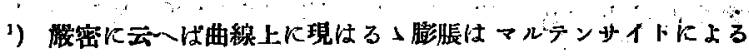

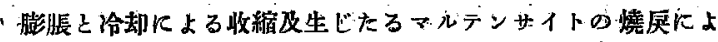
る收緮との差である。 
イトの゙減小になると咵へる時はマルテンサイト化速庭は空 溫に於けるマルテンサイト量 $\mathrm{a}$ 器化しつ〉あるマルテン サイト量 $\mathrm{x}$ との差に比例する管である。因てマルテンサ イト化速度は炏式に依て表はすてとが出桃る

$$
\mathrm{dx} / \mathrm{dt}=\mathrm{K}(\mathrm{a}-\mathrm{x})
$$

この式孝解けば $\mathrm{x}=\mathrm{a}_{\mathrm{a}}\left[1-\mathrm{e}^{-\mathrm{K} t}\right)$, 或は $(\mathrm{a}-\mathrm{x})=2 \theta^{-\mathrm{K} t}$ となる。姑に $\mathrm{t}$ は時間，K は比例常數を示す。從つて

$$
\mathrm{K}=1 / \mathrm{t} \cdot \log \{\mathrm{a} /(\mathrm{a}-\mathrm{x})\}
$$

となり、得たる曲線に就を算出するととが出來る。又承む
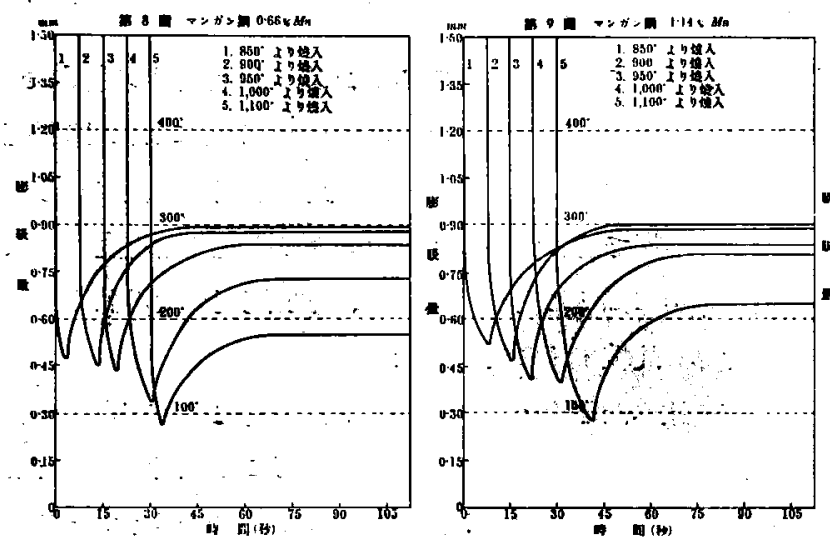

西速度は $\mathrm{x}=\mathrm{a} / 2$ なる時つものであるか・ら $\mathrm{dx} / \mathrm{dt}=\mathrm{Ka} / 2$

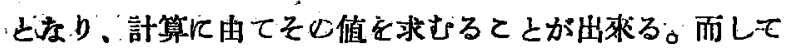
$\mathrm{dx} / \mathrm{dt}=\mathrm{Ka} / 2$ は第 6 圖に於て $\mathrm{T}$ 點に切線を引く時 $\alpha$ の 正切在表はす。第 3 表は $0.73 \% 、 0.92 \%, 1.06 \%, 1.12$ \% $C$ なる 4 程の炭素鋼に就て得たる燒入曲倸より求めた

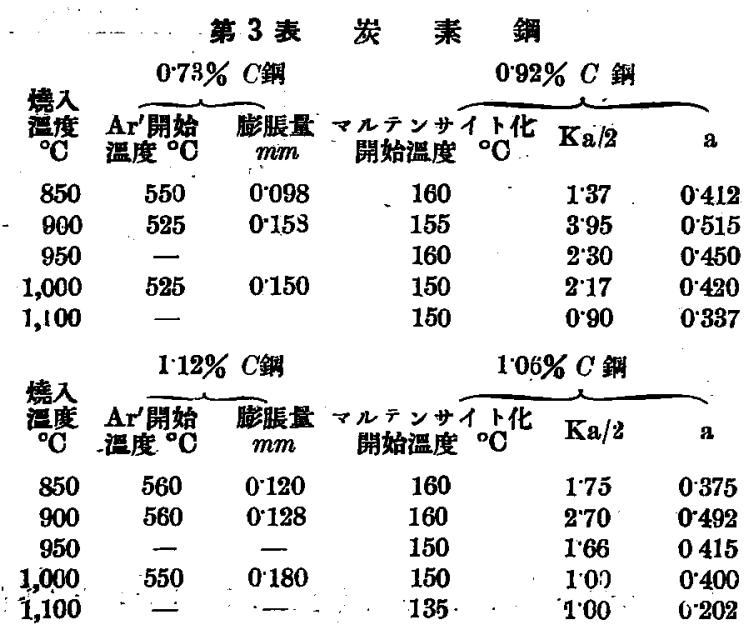

$\mathrm{Ar}^{\prime}$ の開始溫溫度!膨脹量：或はマルテンサイト化開始溫 度。宁ルテンサイト化速度 $\mathrm{Ka} / 2$ 及び室溫に於けるマル テンサイト量、し值を示す。及第 7 圖は $0.92 \%$ 及び 1.06 $\% C$ 鋼几就き $\mathrm{Ka} / 2$ 及 $\mathrm{a}$ 值を圖示したものである。 之に由て見れば炭素鐦に於ては $0.92 \% C$ の歹のは 1.06
\%Cのbのに比して $\mathrm{Ka} / 2$ 及び a の值が大である。てれ は $0.92 C$ の のは共析鋼儿近く. 1.06\% Cのbのは過 其析錭で初析セメンタイトを含有するためである。邓 $\mathrm{Kal}$ 2 及び a の值は $900^{\circ} \mathrm{C}$ 上り溹入せるものが熶大て、それ

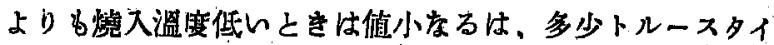
トを生するためで、燒入溫度 $900 \mathrm{C}$ 以上下上䒜する時值 が小となるは，前述の如く残留オースデナイトを生するた めである。

VI. マンカン鋼の燒入曲線 第 $8 \sim 11$ 圆は 4 檑のマ

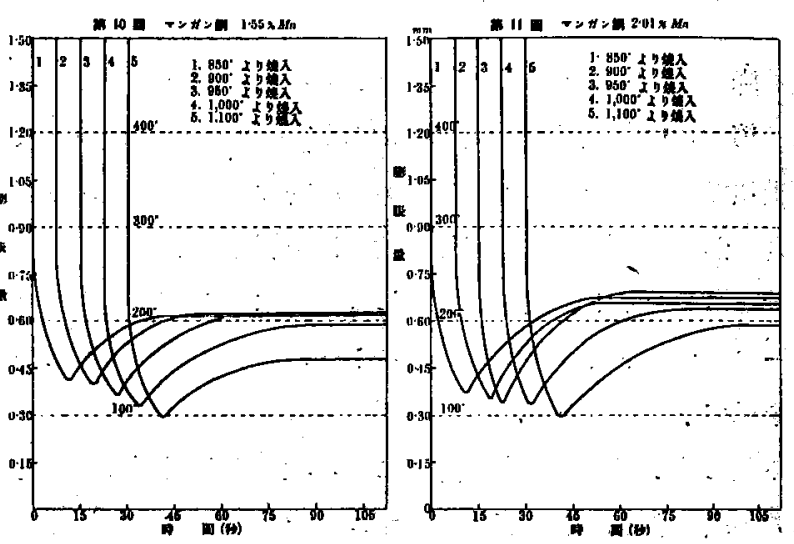

ンガン鐥と就て得をる燒入膨脤一時間曲線を示し、第 4 表

\begin{tabular}{|c|c|c|c|c|c|c|}
\hline \multirow{2}{*}{$\begin{array}{c}\text { 燒入 } \\
\text { 㴓浽 } \\
{ }^{\circ} \mathrm{C}\end{array}$} & \multicolumn{6}{|c|}{ 苐 4 表 マンガン鋼 } \\
\hline & 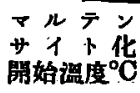 & $\mathbf{K} \mathbf{a} / \mathbf{2}$ & $\mathbf{a}$ & 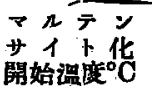 & $\mathrm{Ka} / \overline{2}$ & a \\
\hline 850 & 160 & $4: 00$ & 0.420 & 175 & 278 & 0375 \\
\hline 900 & 150 & $7 \cdot 05$ & 0.435 & 155 & 6.1 & 0.427 \\
\hline 950 & 145 & 466 & 0.420 & 135 & $7 \cdot 50$ & 0.450 \\
\hline ,000 & 110 & $4: 50$ & $0 \cdot 405$ & 130 & 5.50 & 0485 \\
\hline 1,100 & 90 & 267 & $0 \cdot 3 c 0$ & 95 & 416 & 0375 \\
\hline & \multicolumn{3}{|c|}{$1.55 \%$ Mn 銅 } & \multicolumn{3}{|c|}{$201 \% M n$ 銅 } \\
\hline $\begin{array}{c}\text { 盢度 } \\
{ }^{\circ} \mathrm{C}\end{array}$ & 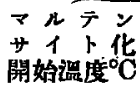 & $\mathrm{Ka} / \mathbf{3}$ & a & 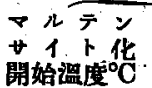 & & a \\
\hline 850 & 140 & $1: 32$ & 0.218 & 125 - & 1.20 & 0.302 \\
\hline 900 & 140 & $1 \cdot 36$ & 0.225 & 120 & 172 & $0 \cdot 305$ \\
\hline 950 & 120 & $1 \cdot 32$ & $0: 270$ & 115 & 237 & $0: 350$ \\
\hline 1,000 & 110 & $1: 33$ & 0250 & 115 & $1 \cdot 37$ & 0315 \\
\hline 100 & 100 & 0.82 & 0180 & 100 & 0.91 & 0.360 \\
\hline
\end{tabular}
代其膨起速度 $\mathrm{Ka} / 2$ ，膨脹量 $\mathrm{a}$ 及マルテンサイト化開始溫

度を表示し、第 12 圖は之を圖示しだすのである。之に舟 て見るとマンガン鋼の膨脹速度及ひ膨脹量はマンガン会量

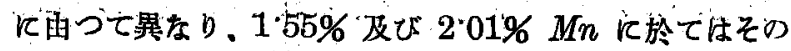
速度並儿量は小さんが、其最大沈なる燒入溫度は No:1

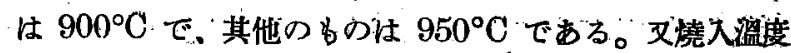
の上昇之共にマルテンサイト化開始盢度は著しく降下し： $M n$ 量の多いbの程その罝度は低く、且つ燒入溫度に因る 
マルテンサイト化開始㴔度の差汢少くなる傾向を有する。

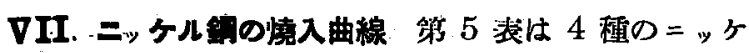

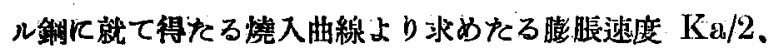

\begin{tabular}{|c|c|c|c|c|c|c|}
\hline \multirow{2}{*}{$\begin{array}{l}\text { 想入 } \\
\text { 泹庭 } \\
{ }^{\circ} \mathrm{C}\end{array}$} & \multicolumn{2}{|c|}{ 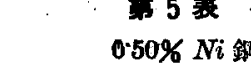 } & & \multicolumn{3}{|c|}{. $0.90 \% \mathrm{Ni}$ 銅 } \\
\hline & 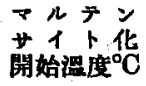 & $\mathrm{K} \boldsymbol{\Omega} / \mathbf{z}$ & a & 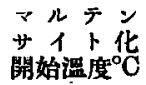 & $\mathrm{Ka} / \mathbf{z}$ & $a$ \\
\hline 830 & 125 & 2.08 & 0.250 & 150 & $1 \cdot 45$ & 0.195 \\
\hline 900 & 115 & 300 & 0.315 & 120 & 285 & 0.300 \\
\hline 950 & 100 & $4 \div 10$ & 0.338 & 115 & $3 \times 30$ & 0.345 \\
\hline 1,000 & 100 & 490 & $0: 368$ & 110 & 500 & 0.375 \\
\hline 1,100 & 95 & 189 & 0.225 & 100 & 200 & 0.240 \\
\hline 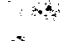 & \multicolumn{3}{|c|}{ 1.47\% Ni 銅 } & \multicolumn{3}{|c|}{$1.91 \% N i$ 銅 } \\
\hline $\begin{array}{l}\text { 温度 } \\
{ }^{\circ} \mathrm{C}\end{array}$ & 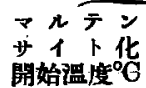 & $\mathbf{K a} / \mathbf{2}$ & a & 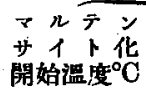 & $\mathrm{Ka} / \mathbf{2}$ & a \\
\hline 850 & 150 & 1.79 & 0335 & 145 & 1.21 & 0.345 \\
\hline 900 & 135 & 187 & 0.345 & 145 & 1.91 & 0.345 \\
\hline 950 & 125 & 322 & 0.360 & 125 & $2 \cdot 18$ & 0360 \\
\hline, 000 & 110 & 400 & $0 \cdot 390$ & 100 & 283 & $0: 385$ \\
\hline 1,100 & 100 & $1 \cdot 15$ & 0.225 & 90 & 0.84 & 0.278 \\
\hline
\end{tabular}

膨脹量 $\mathrm{a}$ 及マルデンサイト化閉始溫度を表示したもので第 13 圖仙之を圖示したものである。(燒入曲線は之を略す)。 之に由て見れば $N i$ 鋼に於てはマルテンサイト化速度は $N i$ 量に影響されること比較的少さく，その變化量子亦差 劦少的。而してマルテサイト化開始溫度は燒入溫度の上昇 之共に降下するが、必しも炭素及び=ッケル量に因り大なる

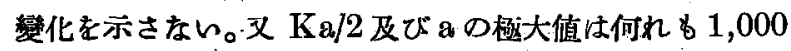
。C 燒入の場合である。乙の場合 $N i$ 量が燴加するに從つ て Ka/2 の值に減少し、aの值恃相接近する。

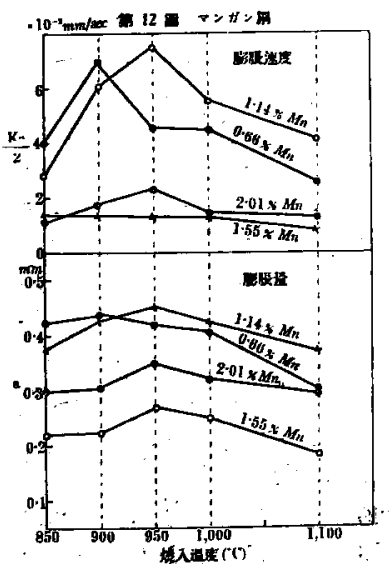

VIIII. コくルト銅の燒入曲線 第 6 表及び第 14 圖壮 4 㯵のコバルト鋼に就て得たる結果を示す。コパルト鋼仗 何れの場合江於ても其膨脹速度頗る小く、膨脤量も:1.0\%

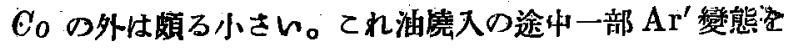
起し:トルースタイトを生するためである。而して 1:94\%

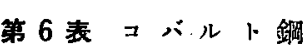

\begin{tabular}{|c|c|c|c|c|c|c|c|}
\hline & \multicolumn{3}{|c|}{$0.55 \%$ Co 銅 } & \multicolumn{4}{|c|}{$1.00 \%$ Co 銅 } \\
\hline $\begin{array}{l}\text { 罝度 } \\
{ }^{\circ} \mathrm{C}\end{array}$ & 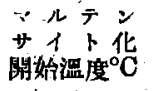 & $\mathrm{Ka} / 2$ & a & & 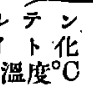 & $\mathrm{Ka} / 2$. & $\mathbf{a}$ \\
\hline$\varepsilon 50$ & 50 & $1 \cdot 43$ & 0.075 & & 110 & $1 \cdot 27$ & $0.2 ! \cdot 8$ \\
\hline 900 & $\therefore 150$ & 166 & 0.075 & & 100 & 290 & 0435 \\
\hline 950 & 140 & 240 & $0.09 \pm$ & & 160 & 3.00 & 0.450 \\
\hline 1,000 & $\therefore 125=$ & 200 & $0^{\prime} 094$ & & 90 & $2 \cdot 11$ & 02885 \\
\hline 1,100 & 100 & 170 & 0.075 & & 75 & 1.09 & 0225 \\
\hline & \multicolumn{3}{|c|}{$153 \% \mathrm{Co}$ 鋮 } & \multicolumn{4}{|c|}{$194 \%$ Co 銅 } \\
\hline $\begin{array}{l}\text { 溫度 } \\
{ }^{\circ} \mathrm{C}\end{array}$ & 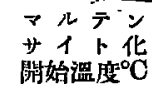 & $\mathbf{K a}$ & & a & $\begin{array}{l}\mathrm{Ar}^{\prime} \\
\text { 開始湮 } \\
{ }^{\circ} \mathrm{C}\end{array}$ & & $\begin{array}{c}\text { 膨脤盟 } \\
m\end{array}$ \\
\hline 850 & 135 & $2 \cdot 17$ & & 0.195 & 510 & & 0.120 \\
\hline 900 & 110 & $2 \cdot 50$ & & 0225 & 510 & & 0.120 \\
\hline 950 & 100 & 200 & & 0.280 & 500 & & 0.150 \\
\hline 1,000 & 100 & $1 \cdot 60$ & & $0 \cdot 120$ & 500 & & 0.158 \\
\hline 1,100 & 80 & 138 & & 0.120 & - & & - \\
\hline
\end{tabular}

$C o$ は $\mathrm{Ar}^{\prime}$ 變態を起し全然 $\mathrm{Ar}^{\prime \prime}$ 變態を示さない。てれCo-

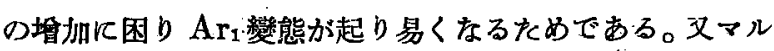
テンサイト化開始溫度は燒入溫度の上䈋に伴し下降す。

IX. バチデウム鋼の獟入曲線 第 7 表及び第 15 圖忙 4 㮔のバナヂウム鋼て就て得たる結果を示す。之に因て見 れば $850^{\circ}$ 燒入に於ては燒入膨脹速度小く。變化量が特に 小さん。方は $V$ の添加因て生市る $V_{4} C_{3}$ がオーズテォ イトに溶解し難く、850 $\mathrm{C}$ では燒入效果が 現はれ難いた めであらら。憢入溫度の上昇之共に膨脹速度及で膨脹量を 增し、呅大を經て減少すること他の添加元素刀場合と网 樣である。一般にバナヂウム鋼 はマルテンサイト化の開始溫度 低く、又燒入溫度の上暴するた めにマルテンサイト化開始温度 の降下すること快、Vの少いる の凡於て著しく、その量太なる bのは少的。

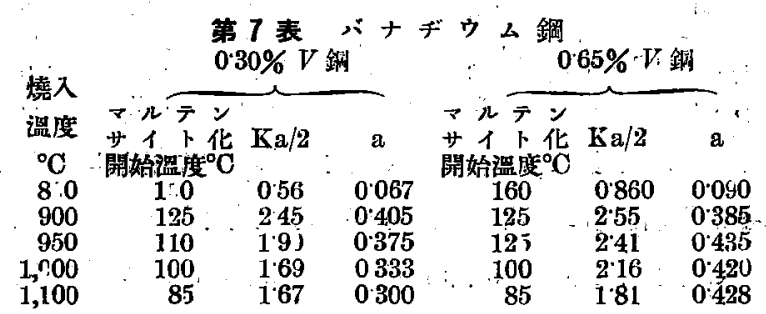




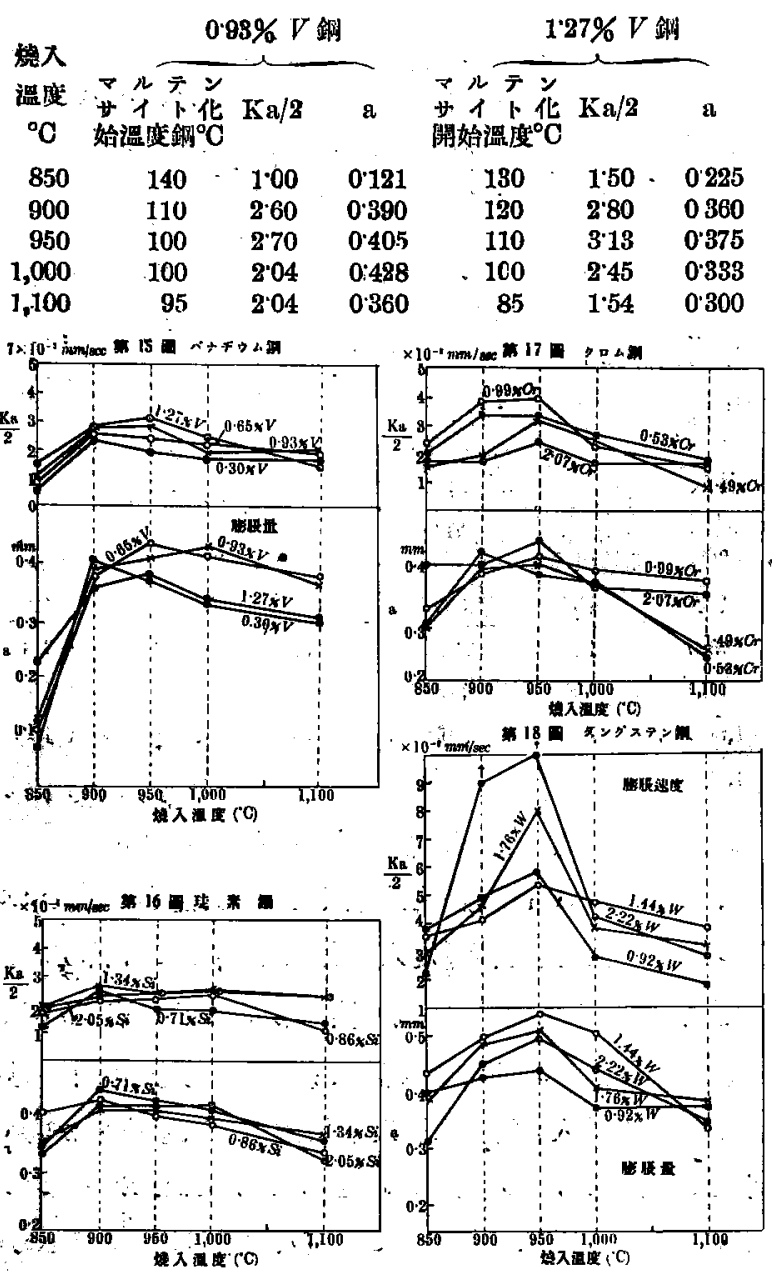

Х: 珪素鈎の燒入曲腺 第 8 装及び第 16 圖は 4 程の 珪素鋼に就て得たる結果を示す。之に由て見れば珪素鋼㤌

萧8老珪素 鋼

\begin{tabular}{|c|c|c|c|c|c|c|}
\hline & $\because \because 0$ & & & & $6 \% \mathrm{Si}$ & \\
\hline $\begin{array}{l}\text { 澅度 } \\
{ }^{\circ} \mathbf{C}\end{array}$ & 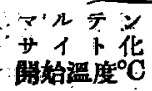 & $\mathrm{Ka} / \mathrm{q}$ & $a$ & 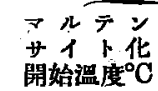 & $\mathrm{Ka} / \mathbf{2}$ & a. \\
\hline 850 & 190 & 1.85 & 0.345 & 180 & 183 & 0.415 \\
\hline 900 & 175 & 260 & 0.450 & 169 & 207 & 0.435 \\
\hline 950 & 160 & 1,00 & 04428 & 160 & 208 & 04405 \\
\hline 1,000 & 160 & 1,87 & 0.420 & 155 & 217 & 0.390 \\
\hline 1,100 & 125 & 139 & $0: 368$ & 125 & 137 & 0.338 \\
\hline & & $4 \% S i$ & & 20 & $5 \% 8 i$ & \\
\hline & 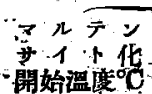 & & $\forall$ & 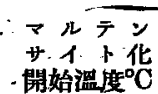 & $\mathrm{Ka} / \mathbf{2}$ & a \\
\hline 850 & 175 & 1.82 & 0.345 & 180 & 1.92 & 0.345 \\
\hline & 165 & 253 & 0.420 & 165 & 2.33 & 0420 \\
\hline 9 & 150 & $2: 26$ & 0425 & 160 & 226 & 0.425 \\
\hline & 150 & $2 \cdot 43$ & 0.40 & 160 & 243 & $0: 420$ \\
\hline & 135 & 227 & $0 \cdot 375$ & 130 & $2 \cdot 27$ & 0.335 \\
\hline
\end{tabular}

概して變熊速度遲く、文燒入溫度及び珪素含有量に因り其 速度及彎化量に大差ない。侣變態開始溫度も一般に高く。

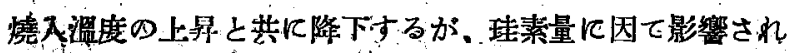

ることが少い。

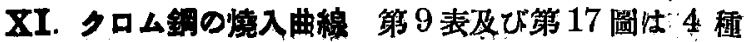

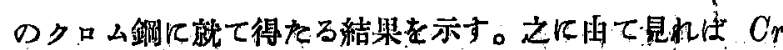
錩は一般にォーステナイトのマルテンサイト化速度は䌊慢

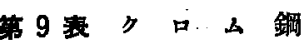
$0.53 \% \mathrm{Cr}$ 堸

\begin{tabular}{|c|c|c|c|c|c|c|}
\hline \multirow[b]{2}{*}{$\begin{array}{c}\text { 爟入 } \\
\text { 罝店 } \\
{ }^{\circ} \mathrm{C}\end{array}$} & \multicolumn{3}{|c|}{$0.53 \% \mathrm{Cr}$ 銅 } & \multicolumn{3}{|c|}{$0.82 \%$ Cr 銅 } \\
\hline & 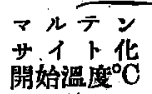 & $\mathrm{Ka} / 2$ & a & 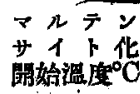 & $\mathrm{Ka} / \mathbf{2}$ & a \\
\hline 850 & 140 & 220 & $0: 300$ & 130 & $2 ; 38$ & Q:325 \\
\hline 900 & 125 & 3.67 & 0428 & 110 & .380 & 0.395 \\
\hline 950 & 100 & $3 \cdot 25$ & $0: 390$ & 100 & 400 & $0 \times 20$ \\
\hline 1,000 & 90 & 277 & $037 i$ & 100 & 230 & 08895 \\
\hline 1,100 & 75 & $1 \cdot 77$ & 0.240 & 90 & 156 & 0.375 \\
\hline & \multicolumn{3}{|c|}{$149 \% C r$ 銅 } & \multicolumn{3}{|c|}{$207 \% \mathrm{Cr}$ 銅 } \\
\hline $\begin{array}{l}\text { 罣入 } \\
\text { 溫度 } \\
{ }^{\circ} \mathrm{C}\end{array}$ & 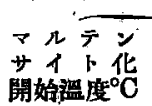 & $\mathrm{Ka} / \mathbf{2}$ & a & 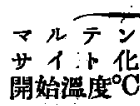 & $\mathrm{Ka} / 2$, & $\begin{array}{c}a \\
1 \%\end{array}$ \\
\hline 850 & 130 & 167 & $0: 300$ & 120 & .180 & $0: 405$ \\
\hline 900 & 110 & 185 & $0: 390$ & 110 & $1: 80$ & 0.405 \\
\hline 950 & 100 & $3: 37$ & 04405 & 105 & 250 & 0450 \\
\hline 1,000 & 100 & $2 \cdot 50$ & $0 \cdot 375$ & 100 & 167 & 0.375 \\
\hline 100 & 80 & 0.81 & 02255 & 75 & 157 & 0.355 \\
\hline
\end{tabular}

てあるがその變化量は頗る大きい。而してその Cr 量に因 る影響は比較的少ないてとを知る。邓マルテンけイト化速 度及びその量は燒入溫度の上昇て件ひて堦少し、極大を經 て減少する。マルテンサイト化開始溫度柱概して低く 150

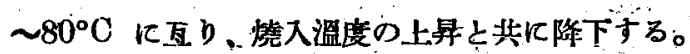

XII. タングステン銅の焼入曲線 第 10 表及び第 18 圆は 4 種のタングステン鋼に就て得をる結果を示す。及第

\begin{tabular}{|c|c|c|c|c|c|c|}
\hline \multirow[b]{2}{*}{$\begin{array}{c}\text { 狫入 } \\
\text { 㴓度 } \\
{ }^{\circ} \mathrm{C}\end{array}$} & & $\begin{array}{l}10 \text { 表 } \\
12 \% W\end{array}$ & \multicolumn{4}{|c|}{$\begin{array}{l}\text { グスデン鋼 } \\
1.44 \% W W \text { 銅 }\end{array}$} \\
\hline & 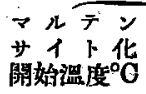 & $\mathrm{Ka} / \mathbf{2}$ & $\mathbf{a}$ & 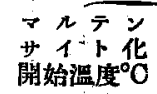 & $\mathbf{K} \mathbf{a} / \mathbf{3}$ & $\mathbf{a}$ \\
\hline 850 & 150 & 3.85 & 0.405 & 160 & 363 & 0.435 \\
\hline 900 & 125 & 4.90 & 0.428 & 150 & 4'14 & 0.495 \\
\hline 950 & 110 & $5 \cdot 80$ & 04435 & 125 & $5 \cdot 45$ & 0.578 \\
\hline 1,000 & 100 & $2 \cdot 78$ & 0.375 & 125 & 485 & $0: 510$ \\
\hline 1,100 & 95 & 178 & 0.375 & 100 & 3.85 & 0.375 \\
\hline 䏻入 & & $6 \% \mathrm{~W}$ & & $2 \cdot 2$ & $2 \% W$ & \\
\hline 溫度 & 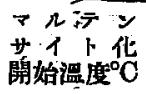 & $\mathrm{Ka} / \mathbf{2}$ & $\mathbf{a}$ & $\begin{array}{l}\nabla \mu \bar{\tau} \\
\forall 1 / \text { 华 } \\
\text { 開始盢度 }\end{array}$ & $\mathbf{K a} / \mathbf{2}$ & a \\
\hline .850 & $\therefore \quad 140$ & 289 & $0: 390$ & 150 & 233 & 0.314 \\
\hline 900 & 180 & 486 & 04488 & 125 & 1500 & 0.450 \\
\hline 950 & 110 & 815 & 0.503 & 110 & 3300 & 0.495 \\
\hline,$\infty 00$ & 100 & 386 & 0.405 & 100 & $4 \cdot 21$ & 0.442 \\
\hline 1,100 & 85 & $\mathbf{3}: 20$ & 0'385. & 90 & $2 \cdot 88$ & 0.345 \\
\hline
\end{tabular}

19 圆山 $2 \cdot 22 \% W$ 試料の燒入曲線寺す。之k由て晃省 よタンダステン銅に於てはオーステナイトのマルフンサイ

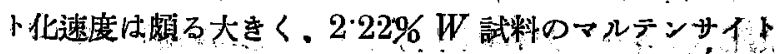



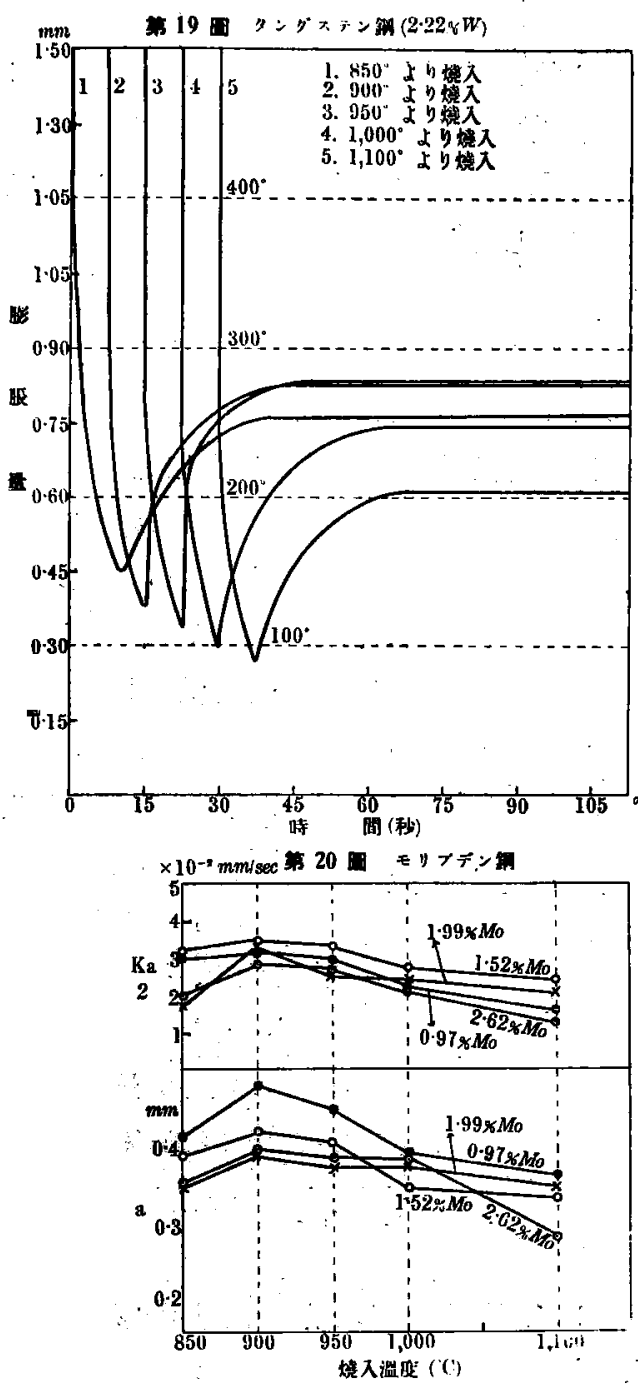

化恃第

19 㵰

に晃る

如く酦

b急激

几起る

而もそ

の變化

量は造

梕大き

sho 及

燒入温

度によ

ろ變化

女著し

$<.950$

${ }^{\circ} \mathrm{C} \mathrm{r}$

於て最

高储を

示し.

$1,000^{\circ}$

以上に

於て敀

低低下

5。

マルテンサイト化開始溫度も一般に低く、燒入溫度の上景 と共に降下するが $W$ 量による影響は少い 低タングステ ン鋼は工具鋼として多く用ひられるるのであるが、此の如 くマルテンサイト化速度大なるため燒割を生じ易く、燒入

第 11 表モリブ ヂン銓

\begin{tabular}{|c|c|c|c|}
\hline & \multicolumn{3}{|c|}{$097 \%$ Mo 銅 } \\
\hline 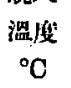 & 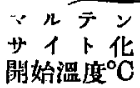 & $\mathrm{Ka} / 2$ & a \\
\hline 850 & 160 & 3.06 & 0415 \\
\hline 900 & 125 & 325 & 0.480 \\
\hline 950 & 110 & 300 & $0.4: 0$ \\
\hline 1,000 & 100 & $2 \cdot 36$ & 0290 \\
\hline 1,100 & 75 & 160 & 0.362 \\
\hline
\end{tabular}

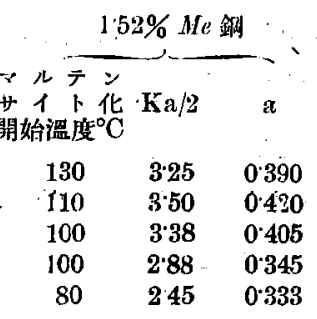

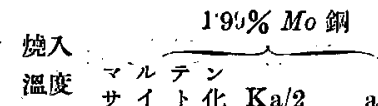

${ }^{\circ} \mathrm{C}$ 開始溫度 ${ }^{\circ} \mathrm{C}$
$\mathrm{Na} / 2$

$\begin{array}{rrrrrrrr}850 & 150 & 180 & 0.355 & & 140 & 2 \cdot 14 & 0355 \\ 900 & 125 & 3 \cdot 12 & 0.390 & & 130 & 2 \cdot 90 & 0390 \\ 950 & 100 & 261 & 0375 & \cdots & 125 & 278 & 0.385 \\ 1,000 & 90 & 2 \cdot 50 & 0.375 & & 100 & 2 \cdot 21 & 03380 \\ 1,100 & 80 & 2 \cdot 10 & 0.345 & & 75 & 1 \cdot 35 & 0 \cdot 285\end{array}$

量は何れ夕頗る大きく、900 ${ }^{\circ} \mathrm{C}$ 燒入に於て淺い極大子示 す。燒大溫度の上昇之共にマルテンサイト化開始溫度は次 第に降下し $150 \sim 80^{\circ}$ に互る。

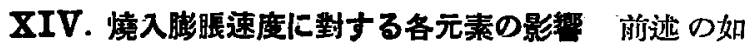
く鋼の燒入膨脹速度は其蒸加元素並に其量に因り影響され る事甚だ大である。第 21 圆恃前記試料に於ける崖素量を 一定上見做し、特殊元装老䄪 $0.5 \%$ 合有する試料儿就て燒 入溫度 $850,900,950,1,000,1,100^{\circ} \mathrm{C}$ 亿於ける膨脹速 度 $\mathrm{Ka} / 2$. 及び膨脹量 $\mathrm{a}$ の變化を各添加元素に就て比较せ るものである。之に因て見るに Ka/2の値はマジガ銓に

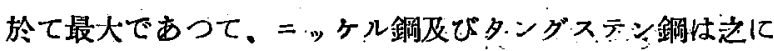

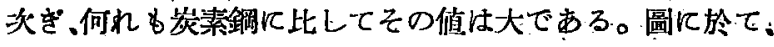

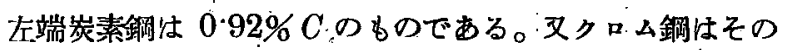

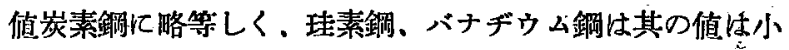
さい。膨脹量ａの值は何れも炭素鋼より小さく、特をさバ ルト鋼㳉著しくその值小で、ニッケル鋼これに次ぐ。他忏 一般にその做に大差圷的。
操作に注意を要するのでする。

XIII. モリブデン銅の憢入

曲線 第 11 表及び第 20 圖は 4 種のモリブデシ鋼て就て得たる 結果を示す。之に因て見ればモ リプデン銅は一般にオーステナ イトのマンテルサイト化速度も。 其變化量 \& $M 0$ の含有量に因 り大なる影響を受けるてとな く略同樣であり、又燒入溫度に、 因方熊化は少へ。併しその變化
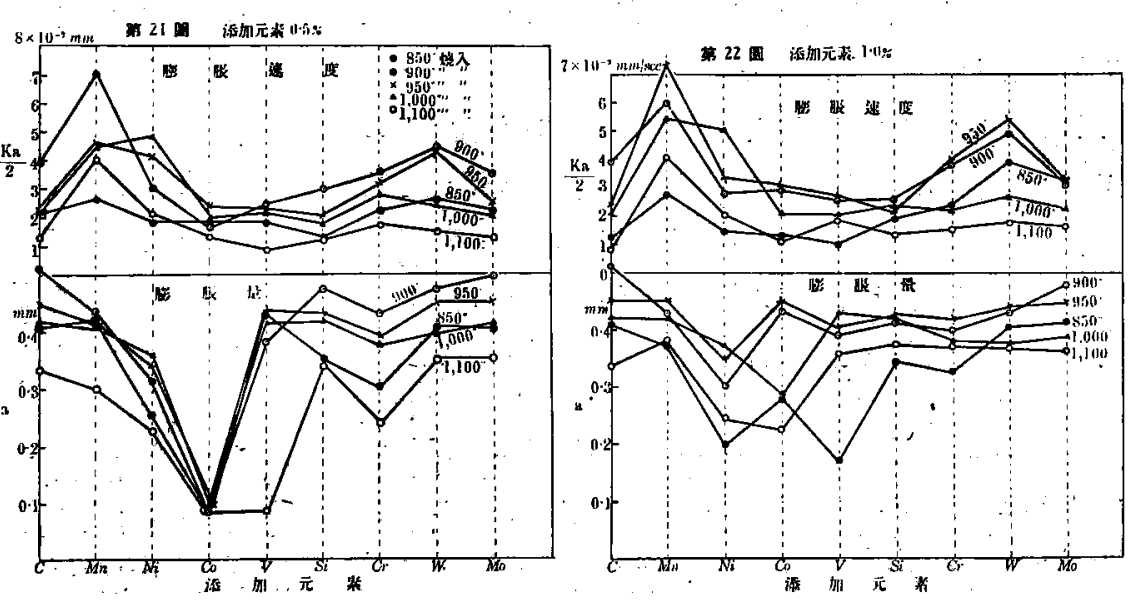
第 22 圆恬添加宇絭約 19 の場合を示す。此の場合に

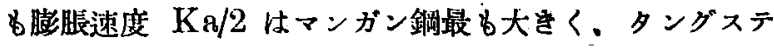
ン鋼これに次ぐ、メ $C o$ 鋼、V 鋼及び $S i$ 鋼はその值为: 小さn。 $N i$ 鋼、Cr 鋼及び $M o$ 鋼住 $C$ 鋼つ值汇近的。 膨脤量は特殊元素の量を堵すと從つて鼻ろ減少する傾向 を示す。Ni 鋼仕その值最小：ある。他は添加元素儿因る 影響は餘り甚しくない。

第 23 圖は添加元素約 $1.5 \%$ の場合の膨脹速度と $\mathrm{Ka} / 2$ 之膨脹量 a の比較を示すむのである。乙の場合 $\mathrm{Ka} / 2$ は $M n$ 鋼が著しく小さくこれマ次で $S i$ 鋼が小さいが. 何れ もその值に著しい差がないＷ鋼のみ大なる值を示す。

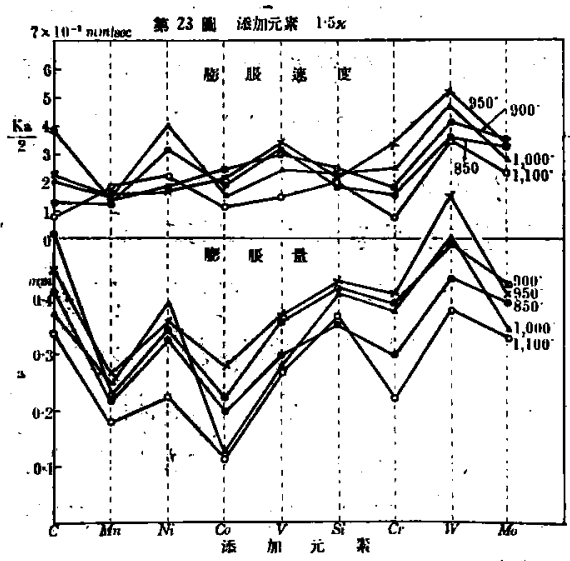

aに就レては $W$ 鎆が最大で、C 鋼はてれと次ぐ。他は 何れも炭素銅上りむ小さく、Co 鋼は最小である。

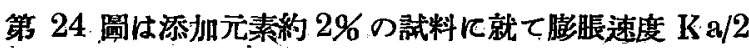
及ひ膨脹量 a の戀化を添加元素に因て比较したすのであ

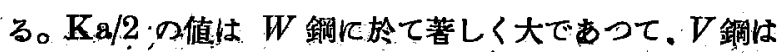

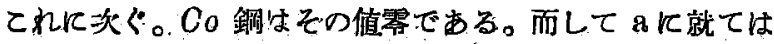
同樣 $C o$ 鋼は零でマルテンサイト化は認められない。 $W$ 鋼

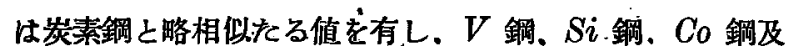
び Mo 鋼は稍炭素銅よりも小さん。

XV. 結言 (1) 鋼の燒入膨脹速度飞對する添加元素の 影響を知るため。燒入膨脹自記裝置を製作し、炭素量を略 一定にして, 2\% 以下の $\mathrm{Mn}, \mathrm{Ni}, \mathrm{Co}, \mathrm{V}, \mathrm{Cr}, \mathrm{Si}, \mathrm{W}$,

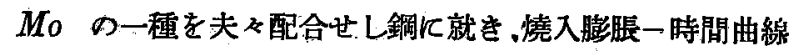
を描かしめ燒入膨脹速度儿對する添加元素の影響を研究し た。又燒入溫度を $850 、 900 、 950,1,000,1,100^{\circ} \mathrm{C}$ 亿變 化し、油燒入せる場合几就て燒入溫度の影響を研究した。

（2）燒入膨骨速度は各乖料几於けるオーステナイトのマ ルテンサイト化て歸因する膨脹時間曲線上り次式㳊因て求
めた。 $\mathrm{dx} / \mathrm{dt}=\mathrm{K}(\mathrm{a}-\mathrm{x})_{\mathrm{o}}$ 茲飞 $\mathrm{x}$ は $\mathrm{t}$ 時間までに變化した

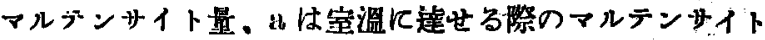
量、 $\mathrm{K}$ は比例常数である。而して本實驗に於ては $\mathrm{x}=\mathrm{a} / 2$ なる瞬間の $\mathrm{dx} / \mathrm{dt}$ 即 Ka/2 几由てマルテンサイト化によ る膨脹速度比较した。

（3）一般に膨脹速度 $\mathrm{Ka} / 2$ 及ひ膨脹量 a の值は何れ。 燒入溫度に由て變化し、900〜 $1,000^{\circ} \mathrm{C}$ 亿植大值を有する。 ヌマルテンサイト化開始溫度は燒入溫度の高い程低ん。

（4）炭素鋼は共析組成に近きものは油燒入に由りマルテ

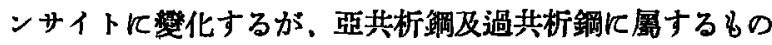
には油燒入に由てはトルースタイトになり易い。而して膨 涱量 a は一般に大で、特殊元素 を添加すると察ろ隇少するに傾向 がある。

（5） マンガン鋼は $950^{\circ} \mathrm{C}$ 燒入 飞於て膨脹速度及び膨脹量住極大 を示す。ヌ $M n$ 量 1.14\%の の のは其值最も大で、それれよす量 が多い時は小さくなる。

(6) = ヶ ル銅恃燒入溫度

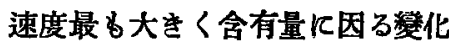
$1,000^{\circ} \mathrm{C}$ 亿於て膨脹量及び膨脹

は稌り著しくない。

(7) コバルト鋼は膨脹度著しく小さく、 $1.94 \% C o$ のも のは油燒入に由て $\mathrm{Ar}^{\prime}$ 變態を起し、マルテンサイト化は 証められない。 $0.55 \%$ Co のすのは膨脹量梗めて小さい が、1.00\% Co k於ては其值大となり.1.53\% Co 以上飞 於て再び減小する。

（8）バナデウ ム鍋性膨脹速度一般て小さく $.900^{\circ} \mathrm{C}$ 橈天

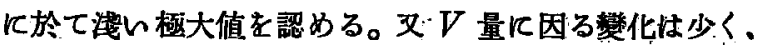
$850^{\circ} \mathrm{C}$ 燒入のものは何れぬ膨脹速度及び膨脹量基て著し く小さい。

（9）珪素鋼の膨脹速度亚に膨脹量性餘り大きくない。

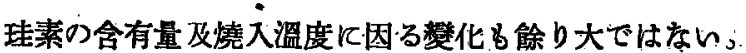

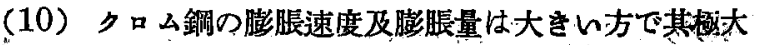
值は大體 $950^{\circ} \mathrm{C}$ である。

(11) タングステン鋼の膨脤速度及膨镺量は最 大き く、Wの含有量篔加する程その值は大となり、176\% $W$

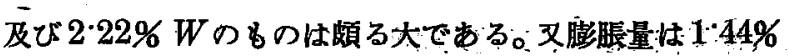
$W$ のものが最大光的。 
（12）モりブデン鋼の赺脹速度及膨腿量は可成り大き

く、燒入溫度に因り影響されるととは少らが，含有量の增 加穴て为分膨脹量を減小する。

“(13) 䄪等量の添加元尧による膨脹速度を比較するとき
は添扣元素 $0.5 \%$ 及び $1.0 \%$ の場合には $M n$ 跧が速度 最も大きく、W 銅之に次ぐが、1.5\% 以上に於では $W$ 鋼最も大き认。

\section{，白:鉄 鑄 鐵の脫炭に，就て(第 2, 報)}

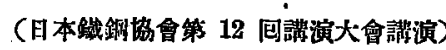

內 藤 逸 “策”

THE DECARBURISATION OF WHITE CAST IRON

(The second report)

By Issaku Naito.

SYNOPSIS:- When white cast iron is annealed with iron oxide in the same vessel, there occures the decarburisation in the casting as explained in the first report; and in the second report, the mechanism on the decarburisation of white cast iron at high temperature is principally explained.

- The change of distribution of carbon in the white cast iron during decarburisation is very complicated commparing in the case of carbon steel, because there are many sources of carbon as temper carbon or free cementite in the matrix of audtenite. However; if the properties of these. sources of carbon were studied, the migration of carbon in the cast iron could be treated by the diffision theory of carbon as in the case of carbon steel. And the mechanism of the decarburisation was presumed after many experimental observations and mathematical treatments on the distribution of carbon in the decarburized sample.

The effect of graphitization and the chemical composition of wbite cast iron on the decarbprisation was also investigated.

\section{1. 緒 論}

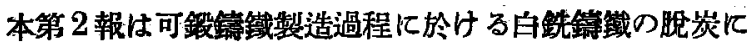
就ての研究であつて、爐內の瓦斯の變化に就て行つた第 1 報の繶きである、主として䥂鐵內に起きる脫炭に伴ふ炭素 の移動を豈測し、其の脫炭の機構支明炕世んとしたので ある。

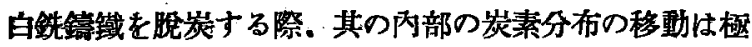
めて複雜であるが、其の理由はセメンタイト及は燒鉱黑鉛 の如を炭素の源となるべきものが澤山に點在するてとに原 因辛るのですて，此等の炭素源の性質を吟味して。白銑

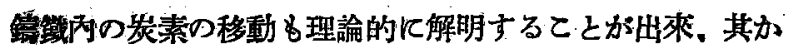
ら脫炭の機構も推定するととが出來たのでする。な海本報 告には脫炭と黑銛化との關係、並に各種成分の脫炭に對す る影響等をむ寞驗し其等の關係む明にすることが出來た。

\section{2. 鋼の脫岩に就て}

鑄鐵の脫炭に就ては今日な疼充分な文綝がないので、先 つ鋼に就て脫炭の一般的機構を考究するととなする。鋼の

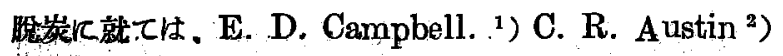

\section{* F畑等物会社}

1) E. D. Campbell; Journal of the Iron \& Steel :Inst. . No. II 1919.

) C. R. Austin;
No, I. 1922.
及び Johansson ${ }^{3}$ ) and Von Seth 等の研究がある。. Austin の實驗は水素瓦斯中で鋼を脫炭させた的のであ つて、其の脫炭の機棈としては炭素の撗散のみでなく、水素 瓦斯の侵入䐋出も考人られてみる。 Johansson 等の實驗 は $\left(\mathrm{CO}+\mathrm{CO}_{2}\right)$ 系の瓦斯によつて脱炭を行つてみるが、其 の結果に對しては何等此の點に就て論ぜられてるない。鐵 鋼の脫炭される機構としては外部より瓦斯が浸大しして炭素 と結合し再び外部に脫出する方法と、队部の炭素が表面人 振散して柬て表面で外氣と結合するてと〉の二方法が拷人

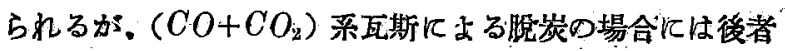
師ち炭素の撗散に上つて脫炭が行は祀る如く見られる。よ つて炏に Johansson 等の實驗結果に就て摭散の法則令適 用し得らるいや否やを數學的に考察して見

鋼は 900 C 以上では全部オーステナイト組織となつて 居るべきで、炭素は其の濃度の美に比例して連續的に高濃

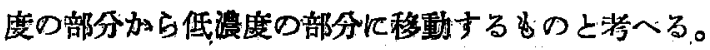

さすれば一般の掋散の微分方程式 (1)にょつて其の炭素 の移動狀態を聅ることが出來る。

$$
\partial \mathrm{w} / \partial \mathrm{t}=\mathbf{k}\left(\partial^{2} \mathrm{w} / \partial \mathbf{x}^{2}+\partial^{2} \mathrm{w} / \partial \mathrm{y}^{2}+\partial^{2} \mathbf{w} / \partial \mathbf{z}^{2}\right) \cdots \cdots(1) .
$$

s) Johansson \& Von Seth; Journal of the Iron \& Steel Inst. No. II. 1926. 